\title{
PENERAPAN MODEL PEMBELAJARAN FLIPPED CLASSROOM BERBANTUAN GOOGLE SITES UNTUK MENINGKATKAN KEAKTIFAN DAN HASIL BELAJAR IPS
}

\author{
WARYANA \\ SMP Veteran 1 Manyaran \\ e-mail: waryana.ratna@gmail.com
}

\begin{abstract}
ABSTRAK
Tujuan yang akan dicapai dalam penelitian ini adalah: (1) Untuk mengetahui apakah penerapan model pembelajaran Flipped Classroom Berbantuan Google Sites dapat meningkatkan keaktifan belajar siswa pada mata Pelajaran IPS kelas VIIIA semester 1 SMP Veteran 1 Manyaran Tahun Pelajaran 2021/2022. (2) Untuk mengetahui apakah Model Pembelajaran Flipped Classroom Berbantuan Google Sites dapat meningkatkan hasil belajar siswa SMP Kelas VIIIA dalam mata pelajaran IPS. Penelitian ini diharapkan dapat bermanfaat: (1) Bagi guru sebagai bahan masukan tentang penggunaan Model Pembelajaran Flipped Classroom Berbantuan Google Sites dalam pembelajaran IPS untuk meningkatkan keaktifan Belajar belajar siswa, (2) Bagi siswa diharapkan dapat meningkatkan keaktifan dan hasil belajar pada mata pelajaran IPS. Hasil Penelitian menunjukkan bahwa penerapan model pembelajaran Flipped Classroom Berbantuan Google Sites mampu meningkatkan keaktifan siswa dari prosentase keaktifan belajar pra siklus sebesar $31 \%$ meningkat pada siklus 1 menjadi $75 \%$, dan pada siklus 2 menjadi $94 \%$. Bahwa Model pembelajaran Flipped Classroom Berbantuan Google Sites mampu meningkatkan hasil belajar siswa dari rata-rata 72,50 pada pra siklus menjadi rata-rata 75,63 pada siklus 1 dan 80,63 pada siklus 2. Pada akhirnya peneliti berharap hasil penelitian tindakan kelas ini dapat digunakan oleh para guru sebagai salah satu alternatif dalam pembelajaran untuk meningkatkan minat dan hasil belajar siswa dalam pelajaran IPS khususnya, dan semua mata pelajaran pada umumnya.

Kata Kunci : keaktifan belajar, hasil belajar, Flipped Classroom, Google Sites.
\end{abstract}

\section{ABSTRACT}

The objectives to be achieved in this study are: (1) To find out whether the application of the Google Sites-Assisted Flipped Classroom learning model can increase student learning activity in the Social Sciences subject for class VIIIA semester 1 of Veteran 1 Manyaran Middle School in the 2021/2022 academic year. (2) To find out whether the Flipped Classroom Learning Model Assisted by Google Sites can improve the learning outcomes of SMP Class VIIIA students in social studies subjects. This research is expected to be useful: (1) For teachers as input on the use of the Google Sites-Assisted Flipped Classroom Learning Model in social studies learning to increase student learning activity, (2) For students, it is expected to increase activeness and learning outcomes in social studies subjects. The results showed that the application of the Google Sites-Assisted Flipped Classroom learning model was able to increase student activity from the pre-cycle learning activity percentage of $31 \%$, increasing in cycle 1 to 75\%, and in cycle 2 to 94\%. That the Flipped Classroom Learning Model Assisted by Google Sites is able to improve student learning outcomes from an average of 72.50 in the pre-cycle to an average of 75.63 in cycle 1 and 80.63 in cycle 2 . In the end, the researcher hopes that the results of this classroom action research can be used by teachers as an alternative in learning to increase student interest and learning outcomes in social studies in particular, and all subjects in general.

Keywords: active learning, learning outcomes, Flipped Classroom, Google Sites,

\section{PENDAHULUAN}

Ilmu Pengetahuan Sosial (IPS) adalah salah satu mata pelajaran yang harus diajarkan pada siswa tingkat SMP mempunyai tujuan antara lain: 1)agar siswa memiliki kemampuan 
dasar berpikir kritis dan logis, rasa ingin tahu, inkuiri, memecahkan masalah,dan ketrampilan dalam kehidupan sosial, 2) mampu berkomunikasi, bekerjasama, berkompetisi dalam masyarakat majemuk di tingkat local, nasional maupun global (Kemendikbud,2016). Selanjutnya dalam Peraturan Menteri Pendidikan dan Kebudayaan Republik Indonesia No. 22 tahun 2016 tentang Standar Proses Pendidikan Dasar dan Menengah dijelaskan bahwa dalam implementasi proses pembelajaran kurikulum 2013 pada satuan pendidikan dilaksanakan secara interaktif, inspiratif, menyenangkan, dan menantang. Serta dapat memberi motivasi bagi peserta didik untuk aktif berpartisipasi, serta memberi kesempatan seluasnya bagi prakarsa, kreativitas, dan kemandirian menurut bakat, minat, perkembangan fisik serta psikologis peserta didik Untuk itu sangat dibutuhkan kemampuan dan ketrampilan seorang guru IPS dalam mengelola pembelajarannya di kelas. Guru dalam merancang pembelajaran harus memastikan bahwa siswa terlibat aktif, melatih berfikir kritis dan logis, timbul rasa ingin tahunya, mampu bekerja kelompok dan melatih siswa memecahkan masalah. Kemampuan-kemampuan tersebut sangat dibutuhkan siswa dalam memasuki abad 21 ini. Pembelajaran yang aktif, kreatif dan menyenangkan dan ditunjang suasana belajar yang kondusif diharapkan mampu meningkatkan hasil belajar IPS.

Sejak tanggal 18 Oktober 2021 pemerintah kabupaten Wonogiri telah mengijinkan sekolah-sekolah yang telah memenuhi syarat untuk menggelar Pembelajaran Tatap Muka Terbatas (PTMT). SMP Veteran 1 Manyaran merupakan salah satunya. Pembelajaran dilaksanakan secara daring dan luring, dengan pembagian dalam satu minggu siswa belajar 3 hari secara daring di rumah dan 3 hari belajar tatap muka dengan guru di kelas.. Semula guruguru menaruh harapan yang besar pembelajaran bisa berjalan dengan baik. .Namun pelaksanaan PTMT tidak sesuai dengan harapan guru. Berdasarkan pengamatan penulis di kelas VIIIA SMP Veteran 1 Manyaran Tahun Pelajaran 2021/2022, siswa tampak malas-malasan untuk mengikuti pembelajaran. Hal ini nampak ketika diterangkan guru banyak siswa yang tidak memperhatikan. Siswa kurang gairah belajar, malas, asyik dengan kegiatannya sendiri, ngobrol dengan temannya, mengerjakan tugas mata pelajaran lain, pura-pura buka buku,dan cenderung ijin keluar dengan alasan ke belakang. Pada saat penulis mengajar, siswa yang hadir 13 siswa dari 16 siswa. Ketika guru mencoba melempar pertanyaan, siswa tidak ada yang menjawab. Dari hasil penilaian harian yang dilaksanakan tanggal 26 Oktober 2021 diperoleh data siswa yang memperoleh nilai di bawah KKM sebanyak $50 \%$ atau 8 siswa.dari 16 jumlah siswa kelas VIIIA. KKM untuk mata pelajaran IPS adalah 75 . Nilai tertinggi 85 , nilai terendah 50 , dan nilai rata-rata 72,5. Dengan demikian secara klasikal belum mencapai ketuntasan belajar.

Faktor penyebab kondisi tersebut antara lain karena terlalu lamanya siswa melaksanakan kegiatan pembelajaran secara daring, Cahyani, dkk. (2020) menemukan dalam penelitiannya bahwa motivasi belajar siswa yang mengikuti pembelajaran menurun pada saat pandemi covid-19. Selama PJJ guru pada umumnya dalam melaksanakan pembelajaran lebih banyak menggunakan WAG. Biasanya siswa diberi tugas untuk mengerjakan soal, lalu dipoto dan dikirim ke WA guru. Kegiatan tersebut rutin setiap hari. Sementara siswa banyak yang mengeluh karena tidak memiliki kuota, tidak memiliki alat komunikasi sendiri, tugas guru terlalu banyak dan siswa tidak memahami materi pembelajaran. Akibatnya banyak siswa yang terlambat mengirim tugas bahkan tidak mengirim tugas sama sekali. Berdasarkan hasil wawancara dengan sesama guru diperoleh data bahwa siswa semakin menurun keaktifannya. Hal ini dibuktikan semakin sedikitnya siswa yang mengirim tugas atau mengisi absensi kehadiran yang dibuat guru pada google form.

Faktor lainnya adalah guru masih menggunakan model pembelajaran konvensional. Pada pembelajaran tatap muka terbatas guru masih mengandalkan metode ceramah. Guru menerangkan materi sementara siswa mendengarkan dan mencatat.. Selain itu untuk pelaksanaan PJJ guru masih tetap mengirim tugas lewat WAG, belum menggunakan media pembelajaran yang menarik. Alhasil pembelajaran menjadi kurang menarik dan siswa malasmalasan untuk mengikutinya. Apabila keadaan yang demikian itu dibiarkan maka akan berakibat menurunnya prestasi belajar siswa. 
Maka guru harus mengubah cara mengajarnya dengan menerapkan model pembelajaran yang bervariasi yang bisa meningkatkan keaktifan siswa. Pelaksanaan PJJ yang terlalu lama telah menyebabkan terjadinya learning loss pada siswa. Yaitu hilangnya minat belajar siswa yang dikarenakan berkurangnya intensitas interaksi dengan guru. Minat yang hilang tersebut harus dikembalikan melalui pembelajaran yang menyenangkan, menantang, mendorong interaksi multi arah, berkolaborasi sesama siswa dan kompetitif. Sebuah model pembelajaran yang tidak mengharuskan siswa menghafal fakta-fakta dan data-data, mendengarkan ceramah dan mencatat. Akan tetapi sebuah model pembelajaran yang mampu mendorong siswa mengkontruksikan pengetahuan sendiri setelah melalui serangkaian kegiatan pembelajaran. Dalam proses belajar, siswa menggunakan pengalamannya untuk menemukan sendiri, dalam kelompok bermain, mengkonstruksi pengetahuan kemudian memberi makna pada pengetahuan itu. Dengan demikian pembelajaran IPS diharapkan lebih menyenangkan siswa, sehingga tumbuhlah minat untuk belajar IPS. Apabila minat sudah tumbuh, maka siswa akan aktif dalam mengikuti pembelajaran.

Untuk mengatasi permasalahan di atas, peneliti menerapkan model pembelajaran Flipped Classroom berbantuan Google Sites. Menurut Bergmann \& Sams (2012) dalam Siti Mutmainah,dkk(2019:4) menyatakan bahwa konsep Model pembelajaran Flipped Classroom adalah membalik aktivitas pembelajaran, yaitu kegiatan pembelajaran yang biasanya dilakukan di kelas dikerjakan di rumah dan mengerjakan tugas-tugas pembelajaran yang biasanya di rumah diselesaikan di kelas. Dengan model Flipped Classroom ini ketika di kelas siswa tidak lagi hanya mendengarkan ceramah guru, melainkan berdiskusi, bekerja kelompok, mengerjakan tugas dengan bantuan temannya atau guru, berlatih memecahkan masalah dengan suasana yang menyenangkan. Sementara ketika di rumah siswa mempelajari materi, menonton video pembelajaran mengerjakan quis interaktif dan membaca LKPD yang akan dilaksanakan di kelas. Dengan berbagai kelebihan yang ada pada Model pembelajaran Flipped Classroom diharapkan mampu meningkatkan keaktifan dan hasil belajar siswa pada pembelajaran Tatap Muka Terbatas (PTMT). Karena pelaksanaan model pembelajaran ini kebalikan dari model pembelajaran konvensional, yang mana mengerjakan latihan/tugas dilaksanakan di sekolah bersama guru, sementara ketika di rumah(PJJ) siswa mempelajari materi yang dikirim beberapa hari sebelumnya oleh guru. Sehingga ketika PJJ di rumah siswa tidak lagi terbebani tugas-tugas dari guru, tetapi hanya mempelajari materi. Tugas yang berupa mengerjakan LKS dikerjakan di sekolah dengan bimbingan guru. Sementara aplikasi Google Sites dimanfaatkan untuk membuat bahan ajar interaktif, karena di dalamnya guru bisa memasukkan materi dalam bentuk Word atau PPT, video pembelajaran, LKPD, quis interakrif, bahan pustaka, dan sebagainya. Pemanfaatan Google Sites diharapkan menarik minat siswa untuk belajar IPS ketika PJJ di rumah.

\section{METODE PENELITIAN}

Penelitian ini adalah penelitian tindakan kelas (classroom action research) yang dilaksanakan secara kolaboratif dan partisipasi, untuk mengatasi permasalahan pembelajaran di kelas. Penelitian tindakan kelas dilaksanakan selama 3 bulan, dimulai bulan Oktober sampai dengan bulan Desember tahun 2021. Tempat penelitian di kelas VIIIA SMP Veteran 1 Manyaran pada semester I tahun pelajaran 2021/2022. Hal ini dilakukan dengan pertimbangan, di kelas VIIIA ada permasalahan pembelajaran yaitu rendahnya keaktifan belajar siswa yang berdampak pada rendahnya hasil belajar siswa. Adapun subyek Penelitian Tindakan Kelas adalah siswa kelas VIIIA SMP Veteran 1 Manyaran Kabupaten Wonogiri tahun pelajaran 2021/2022. Jumlah siswa sebanyak 16 orang, yang terdiri dari 10 orang siswa laki-laki dan 6 orang siswa perempuan. Data atau informasi berupa data yang menyangkut tentang siswa kelas VIIIA SMP Veteran 1 Manyaran tahun pelajaran 2021/2022, keaktifan belajar, hasil belajar siswa, dan data guru (hasil aktifitas guru). Sumber data meliputi arsip/dokumen, hasil angket keaktifan belajar siswa, aktivitas guru, hasil tes akhir siklus dan foto-foto kegiatan. Teknik pengumpulan data dengan metode angket, observasi,dan tes. Penelitian dilaksanakan dengan 
dua siklus yang masing-masing siklus terdiri dari empat tahapan. Keempat tahapan tersebut adalah: perencanaan (planning), tindakan (action), pengamatan (observation), dan refleksi (reflection). Kegiatan penelitian tiap siklus dilaksanakan dalam 2 kegiatan pembelajaran, yaitu kegiatan PJJ dan kegiatan PTMT. Pada kegiatan PJJ guru mengirim materi untuk dipelajari siswa melalui aplikasi Google Sites. Materi yang berbentuk web pembelajaran ini berisi materi, video pembelajaran, quis dan LKPD. Selanjutnya kegiatan dalam PTMT adalah siswa mengrjakan LKPD secara berkelompok, presentasi dan diakhiri pos tes.

\section{HASIL DAN PEMBAHASAN}

\section{Hasil}

\section{Diskripsi Kondisi Awal}

Dari hasil penyebaran angket dan pengamatan prasiklus, diketahui keaktifan belajar IPS kelas VIIIA SMP Veteran 1 Manyaran tahun pelajaran 2021/2022 masih rendah. Dari 16 siswa, yang nilai keaktifan belajarnya baik hanya ada 5 siswa (31\%), sementara yang 11 orang siswa $(69 \%)$ nilai keaktifannya hanya cukup baik. Ketika diadakan penilaian harian, hasilnya banyak siswa yang nilainya masih di bawah KKM. Nilai KKM sekolah untuk mata pelajaran IPS adalah 75. Rata-rata nilai capaian siswa pada penilaian harian adalah 72,5. Dari 16 siswa kelas VIIIA, yang tuntas hanya 8 siswa $(50 \%)$, sedangkan yang 8 siswa (50\%) belum tuntas. Dengan demikian secara klasikal belum tuntas.

\section{Diskripsi Hasil Siklus 1}

Tindakan siklus 1 dilakukan sebanyak 2 kali pertemuan yaitu hari Selasa, 2 November 2021 jam 1-2 pada Pembelajaran Jarak Jauh (PJJ) dan hari Selasa, 9 November 2021 jam 1-2 pada Pertemuan Tatap Muka Terbatas (PTMT). Langkah-langkah tindakan pada siklus 1 adalah sebagai berikut:

a. Planning (Perencanaan) Siklus 1

Kegiatan ini meliputi penyusunan RPP, menyusun media pembelajaran berbentuk Google sites, menyusun LKPD, membentuk kelompok, menyusun lembar angket dan observasi.

b. Acting(Tindakan)

1) Pada pertemuan PJJ guru mengirimkan materi yang harus dipelajari siswa di rumah dalam Google Sites dan petunjuk-petunjuknya, 2) pada PTMT guru mengawali pelajaran dengan pendahuluan, mempersilakan kelompok berkumpul pada kelompoknya, menjelaskan tugas, membimbing kelompok dalam melaksanakan tugas, mamandu presentasi, membimbing refleksi dan memberikan pos tes serta menutup pembelajaran.

c. Observing (Pengamatan) Siklus 1

Selama pelaksanaan penelitian pada siklus I, diadakan observasi oleh Observer/pengamat terhadap keaktifan siswa dalarn mengikuti proses pembelajaran IPS dengan model pembelajaran Flipped Classroom Berbantuan Google Sites Indikator keaktifan belajar yang diamati berdasarkan lembar observasi yang dipersiapkan oleh guru peneliti.

d. Reflecting (Refleksi) Siklus I

Yang dilakukan pada kegiatan refleksi adalah mengkaji kegiatan-kegiatan yang dilaksanakan pada siklus 1 untuk menemukan kelebihan atau kekurangannya, sebagai bahan untuk melakukan kegiatan di siklus 2. Hasil refleksi digunakan untuk menetapkan langkah selanjutnya guna mencapai tujuan PTK.

\section{Diskripsi Hasil Siklus 2}

Sebagaimana yang direncanakan, maka penelitian tindakan kelas ini dilaksanakan dengan 2 siklus. Siklus ke 2 dilakukan dengan 2 kali pertemuan yaitu pada hari Selasa, tanggal 16 November 2021 jam 1-2 berupa Pembelajaran Jarak Jauh (PJJ)dan hari Selasa, tanggal 23 November 2021 jam 1-2 pembelajaran Tatap Muka Terbatas di sekolah. Langkah-langkah yang dilakukan guru peneliti masih sama dengan langkah siklus 1, yaitu planning (perencanaan), acting (pelaksanaan), observing (pengamatan) dan reflecting (refleksi). Pada tahap siklus 2 ini 
ada perbaikan khususnya tentang pembagian waktu pengerjaan tugas kelompok, agar waktunya bisa efektif. Hal ini berdasarkan evaluasi pelaksanaan di siklus 1.

Selanjutnya hasil pengamatan observer, angket siswa, hasil penilaian harian baik pra siklus, siklus 1 dan siklus 2 dianalisis oleh guru peneliti dengan hasil sebagai berikut :

\section{Hasil Penelitian tentang Keaktifan Belajar}

Peneltian tentang keaktifan belajar siswa dilaksanakan melalui angket dan observasi pada pra siklus, siklus 1 dan siklus 2. Angket dibagikan ke siswa untuk diisi, dan observasi dilaksanakan oleh observer pada saat pelaksanaan PTMT di kelas. Selanjutnya hasil angket dan observasi diolah dengan rumus sebagai berikut :

Prosentase Keaktifan $=\frac{X_{o}+X_{a}}{2}$

Keterangan :

Xo $=$ prosentase keaktifan yang diperoleh dari lembar observasi

$\mathrm{Xa}=$ prosentase keaktifan yang diperolehdari lembar angket

Kriteria prosentase keaktifan belajar siswa

86-100 sangat baik

$71-85$ baik

56-70 cukup baik

41-55 kurang baik

-40 sangat kurang baik

Hasil penelitian keaktifan belajar siswa pada pra siklus, siklus 1 dan siklus 2 disajikan pada tabel dan grafik sebagai berikut:

Tabel 1. Rekapitulasi Keaktifan belajar Para Siklus, Siklus 1 dan Siklus 2

No Kriteria Pra Siklus Siklus 1 Siklus 2

Jumlah Prosentasi Jumlah Prosentase Jumlah Prosentasi

1. Sangat Baik - 0\% $212,5 \% 425 \%$

2. Baik $531 \% 1062,5 \% 1169 \%$

3. Cukup Baik $1169 \% 425 \% 16 \%$

4. Kurang Baik - - - - -

5. Sangat kurang baik - - - . -

Dari Tabel 1 di atas dapat dibuat grafik sebagai berikut :

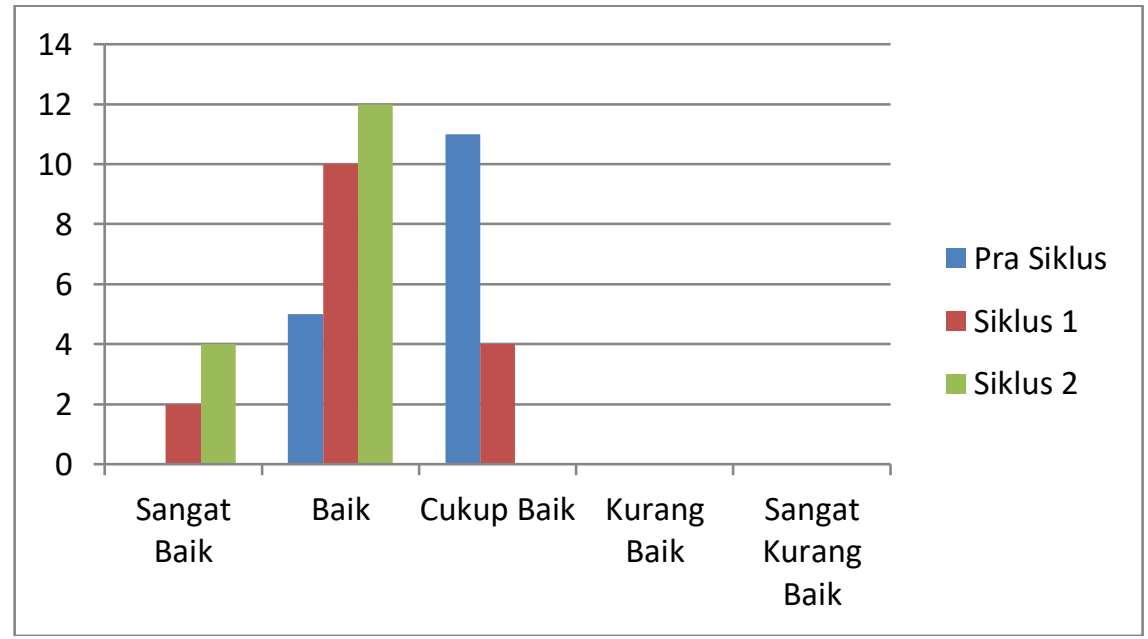

Gambar 1. Grafik Rekapitulasi Keaktifan Belajar Siswa 


\section{Hasil Belajar siswa}

Penelitian hasil belajar siswa diperoleh dari analisis Penilaian Harian yang diadakan oleh guru. Sebelum mengadakan penelitian diadakan Penilaian Harian Pra siklus. Kemudian pada saat penelitian dilakukan Penilaian Harian Siklus 1 dan Penilaian Harian Siklus 2. Hasil dari análisis Penilaian Harian tersebut dapat dilihat pada tabel di bawah ini.

Tabel 2. Hasil Belajar Para Siklus, Siklus 1 dan Siklus 2

\begin{tabular}{|c|c|c|c|c|}
\hline No & Uraian & PraSiklus & Siklus 1 & Siklus 2 \\
\hline 1 & Rata-rata & 72,50 & 75,63 & 80,63 \\
\hline 2 & Nilai Tertinggi & 85 & 100 & 100 \\
\hline 3 & Nilai Terendah & 50 & 45 & 60 \\
\hline 4 & Mencapai KKM & 8 & 11 & 14 \\
\hline 5 & Belum Mencapai & 8 & 5 & 2 \\
\hline 6 & Prosentase Tuntas & $50 \%$ & $69 \%$ & $88 \%$ \\
\hline
\end{tabular}

Dari Tabel 2 tentang hasil Belajar Siswa di atas dapat disajikan dalam bentuk grafik sebagai berikut :

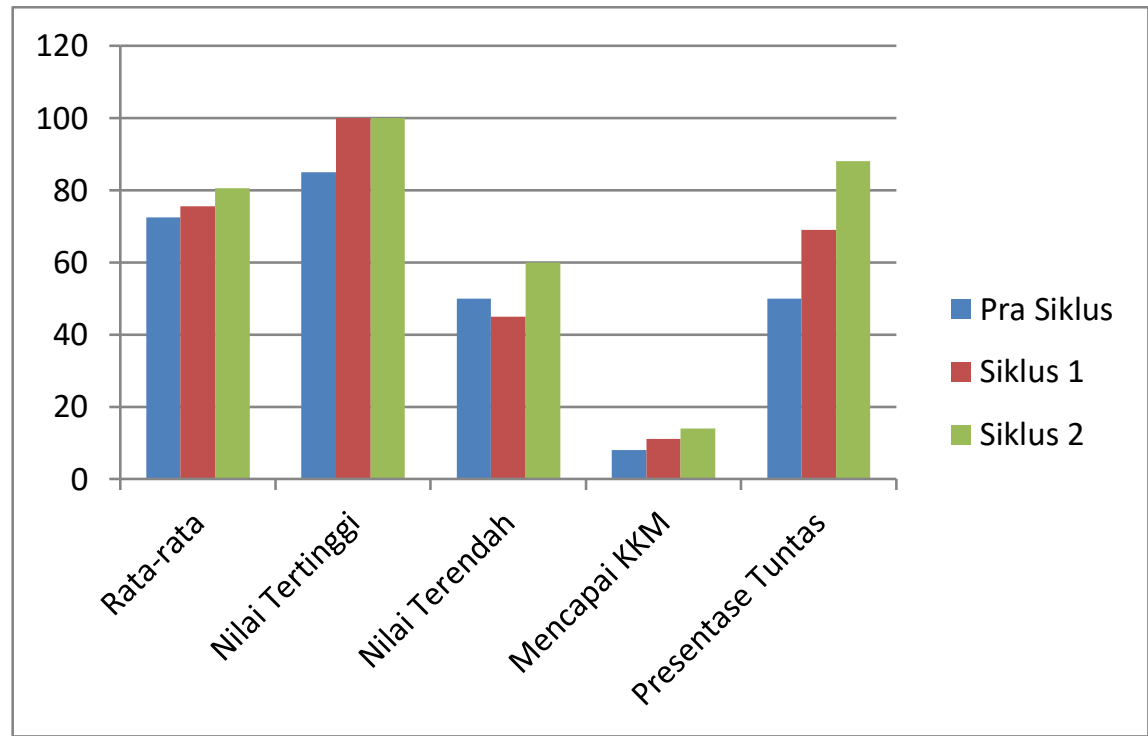

\section{Gambar 2.Grafik Rekapitulasi Hasil Belajar pra siklus, siklus 1 dan siklus 2}

\section{Pembahasan}

Dari hasil penelitian di atas dapat dijelaskan bahwa sebelum guru menerapkan model pembelajaran Flipped Classroom berbantuan Google sites, keaktifan belajar siswa masih rendah. Dari 16 orang siswa, hanya 5 siswa (31\%) yang nilai keaktifannya baik, dan 11 siswa (69\%) dengan kategori cukup. Data tersebut diperoleh dari angket yang diadakan guru sebelum penelitian yang berisi 15 butir pertanyaan, dan observasi yang dilakukan guru menyangkut 10 indikator. Padahal dalam proses belajar mengajar sangat dibutuhkan keaktifan belajar siswa. Bisa dikatakan keaktifan belajar merupakan motor utama kegiatan pembelajaran. Menurut Hamalik (2008:90) keaktifan belajar adalah suatu keadaan atau hal dimana siswa bisa aktif. Sementara Hartono (2008:11) mengatakan bahwa keaktifan belajar adalah proses pembelajaran yang dilaksanakan guru sedemikian rupa sehingga siswa aktif bertanya, mempertanyakan dan mengemukakan gagasan Dari beberapa pendapat di atas dapat disimpulkan bahwa keaktifan belajar adalah suatu proses belajar mengajar yang dilaksanakan guru dimana siswa terlibat aktif baik fisik, mental, intelektual dan emosional dengan bertanya, melakukan, mempertanyakan dan mengemukakan gagasan.

Menurut Nana Sudjana (2004) keaktifan belajar siswa dapat terlihat dari keikutsertaannya dalam menyelesaikan tugas belajarnya. Indikator yang tampak antara lain keikutsertaan dalam memecahkan masalah, bertanya kepada teman atau guru apabila belum 
mengerti, berupaya mencari informasi, melatih memecahkan masalah dan menilai kemampuan diri (Sinar,2018).Indikator tersebut belum tampak pada pembelajaran yang peneliti terapkan. Menurut Widana et al (dalam Rediansyah, 2021) keaktifan siswa secara mental, intelektual, dan emosional dalam pembelajaran akan semakin baik pada penguasaan materi pembelajaran Maka mulai tanggal 2 November 2021 penulis menerapkan pembelajaran dengan menggunakan model Flipped Classroom berbantuan Google Sites di kelas VIIIA.

Model Pembelajaran Flipped Classroom adalah model pembelajaran dimana siswa mempelajari materi pelajaran di rumah terlebih dahulu, baru kemudian ketika di sekolah mengerjakan tugas atau berdiskusi tentang materi yang belum diketahui (Sudarmanto,et al.(2021). Saat ini model pembelajaran Flipped Classroom belum banyak diterapkan oleh guru di Indonesia. Pertama kali diperkenalkan tahun 2000 oleh J.Wesley Baker. Konsep Model Flipped Classroom adalah memadukan pembelajaran di luar dan di dalam kelas guna mengoptimalkan pelaksanaan proses belajar mengajar. Flipped Classroom adalah bentuk pembelajaran blended learning, yang menggabungkan pembelajaran sinkron (sinchronous) dengan pembelajaran asinkron (asinchronous). Pembelajaran sinkron biasanya dilaksanakan secara real time berinteraksi dengan guru dan sesama siswa di kelas. Sementara pembelajaran asinkron dilaksanakan secara mandiri oleh siswa sendiri di rumah. Oleh karena itu cocok kiranya diterapkan pada pemberlakuan Pertemuan Tatap Muka Terbatas (PTMT) seperti saat pandemi covid 19 ini. Pada waktu siswa belajar di rumah, guru mengirim tugas berupa ringkasan materi, video pembelajaran, quis dan LKPD untuk dipelajari siswa. Selanjutnya pada saat PTMT di kelas, siswa dibimbing guru mengerjakan tugas secara berkelompok dan mengerjakan pos tes.

Selanjutnya untuk menarik minat siswa, dalam menyediakan materi pembelajaran siswa ketika belajar di rumah (asinkron) guru memanfaatkan google sites. Yaitu salah satu produk dari google sebagai tools untuk membuat website pembelajaran (Budi Harsanto,2012). Cara memanfaatkan Google Sites tergolong mudah, karena pengguna tinggal drop and drag pada fitur-fitur yang telah disediakan. Kelebihan penggunaan google sites saat ini gratis,mudah dibuat, memungkinkan berkolaborasi dalam pemanfaatannya dan searchable(dapat ditelusuri ) dengan mesin pencarian google. Selain itu guru bisa mengirimkan materi kepada siswa berupa ringkasan materi, video pembelajaran, quis dan LKPD sekaligus dalam satu aplikasi. Cara membuka siswa pun tergolong mudah, tinggal klik link yang telah dikirimkan guru. Karena berbentuk website, maka bisa disimpan dan tidak membebani memory HP siswa. Selain itu materi dapat dibuka berulang-ulang.

Guru segera menyiapkan peneltian tindakan kelas, mulai dari menyusun Rencana Persiapan Pembelajaran, rancangan penilaian, daftar nilai, daftar hadir, lembar angket,lembar observasi, LKPD dan dan membuat materi pada Google sites.. Materi pembelajaran yang akan digunakan pada penelitian ini adalah materi KD 3.2/submateri Pluralitas Masyarakat Indonesia. Pemilihan materi semata disesuaikan dengan urutan materi yang harus disampaikan oleh guru kepada siswa. Hari Selasa, 2 November 2021 pada saat jadwal guru mengajar PJJ, guru mengirimkan materi dalam bentuk website Google sites yang diberi judul IPS Gemilang 2 . Website ini berisi materi bentuk ringkasan, video pembelajaran tentang Pluralitas Masyarakat Indonesia, quis seputar pluralitas keagamaan dari aplikasi wordwall, LKPD yang akan dikerjakan saat PTMT dan referensi/pustaka. Siswa diminta mempelajarinya secara mandiri. Satu minggu kemudian, Selasa,9 November 2021 siswa melaksanakan PTMT di kelas. Siswa dibagi menjadi 5 kelompok , tiap kelompok 3 orang. Tiap kelompok mengerjakan LKPD yang diberikan guru dengan waktu yang ditentukan. Setelah selesai hasil pekerjaan kelompok ditempel di papan tulis. Lalu hasil dikoreksi bersama sama. Kelompok yang menempel paling cepat dan benar diberi hadiah. Pertemuan diakhiri dengan pos tes dimana siswa mengerjakan soal esay dan hasilnya dikumpulkan. Selama kegiatan berlangsung, dilakukan observasi keaktifan oleh guru observer.

Setelah guru menerapkan model pembelajaran Flipped Classroom berbantuan Google Sites, maka terdapat peningkatan baik keaktifan belajar siswa maupun hasil belajar siswa. Pada 
siklus 1 ini jumlah siswa yang nilai keaktifannya baik dalam mengikuti proses pembelajaran sudah mengalami peningkatan dibanding pada kegiatan pra siklus. Pada siklus I, jumlah siswa yang nilai keaktifannya baik ada 10 orang ( 62,5\%), sangat baik 2 orang (12,5\%), dan cukup baik ada 4 orang $(25 \%)$. Jadi pada siklus 1 ada peningkatan keaktifan siswa sebesar $44 \%$. Demikian juga dalam hasil belajar mengalami peningkatan. Jika pada pra siklus, siswa yang mencapai KKM hanya 8 siswa (50\%) dengan nilai rata-rata 72,50, maka pada hasil penilaian siklus 1 meningkat. Siswa yang mencapai KKM menjadi 11 orang (69\%) dengan nilai rata-rata kelas 75,63. Dengan demikian ada peningkatan prosentase siswa yang mencapai KKM sebesar $19 \%$ dari pra siklus. Nilai rata-rata pada siklus 1 juga meningkat dibanding nilai rata-rata pra siklus, yaitu sebesar 3,13.

Pada tanggal 16 dan 23 November 2021 dilaksanakan penelitian siklus 2. Guru peneliti menerapkan persiapan dan kegiatan yang sama dengan siklus 1, dengan sedikit pembenahan sesuai hasil refleksi pada siklus 1. Materi masih membahas Pluralitas Masyarakat Indonesia dengan pokok bahasan yang berbeda dengan siklus 1. Dari hasil pelaksanaan penelitian di siklus 2 diperoleh data ada peningkatan yang signifikan pada keaktifan dan hasil belajar siswa. Pada siklus 2 siswa yang nilai keaktifannya baik ada 11 orang (69\%), sangat baik 4 orang $(25 \%)$ dan cukup baik 1 orang $(6 \%)$. Maka dibanding hasil siklus 1 ada peningkatan prosentase keaktifan siswa sebesar 19\%, atau sebesar 63\% jika dibanding pada keaktifan siswa pra siklus. Demikian juga hasil belajar siswa meningkat. Siswa yang mencapai KKM menjadi 14 orang siswa dan nilai rata-rata kelas menjadi 80,63. Sehingga secara keseluruhan pada siklus 2 terjadi peningkatan prosentase pencapaian KKM sebesar 9\% dari siklus 1. Sementara juga terjadi peningkatan nilai rata-rata sebesar 5,0 dari nilai rata-rata siklus 1 .

Catatan dari hasil penelitian ini antara lain melalui penerapan model pembelajaran Flipped Classroom Berbantuan Google Sites dapat meningkatkan keaktifan belajar siswa pada pembelajaran IPS. Keaktifan tersebut mencapai 94\% dari keseluruhan siswa. Sehingga bisa dikatakan tingkat keaktifan siswa cukup tinggi. Tarigan,D (dalam Dewanti, 2021) mengatakan bahwa siswa disebut aktivitas belajarnya tinggi apabila $75 \%$ dari siswa di kelas tersebut aktif mengikuti pelajaran. Dengan meningkatnya keaktifan siswa berpengaruh terhadap peningkatan hasil belajar siswa. Hal ini sesui dengan hasil penelitian yang dilakukan oleh Amini (2015), yang menyatakan bahwa ketuntasan nilai hasil belajar siswa sangat dipengaruhi oleh keaktifan siswa itu sendiri pada kegiatan pembelajaran.

\section{KESIMPULAN}

Berdasarkan hasil Penelitian Tindakan Kelas dapat disimpulkan bahwa penerapan model pembelajaran Flipped Classroom Berbantuan Google Sites dapat meningkatkan keaktifan belajar siswa kelas VIIIA SMP Veteran 1 Manyaran pada semester 1 tahun pelajaran 2021/2022. Dari hasil penelitian diperoleh data pada saat pra siklus siswa yang nilai keaktifannya baik hanya sejumlah 5 orang (31\%), di akhir siklus 2 siswa yang nilai keaktifannya baik menjadi sejumlah 11 orang (69\%) dan sangat baik 4 orang (25\%). Ini berarti penggunaan model pembelajaran Flipped Classroom Berbantuan Google Sites sangar efektif membangkitkan keaktifan belajar siswa secara signifikan.

Pembelajaran dengan model pembelajaran Flipped Classroom Berbantuan Google Sites dapat meningkatkan hasil belajar siswa kelas VIIIA SMP Veteran 1 Manyaran pada semester 1 tahun pelajaran 2021/2022. Hal ini dibuktikan dengan peningkatan rata-rata nilai penilaian harian. Pada saat pra siklus rata-rata nilai penilaian hariannya adalah 72,50 dan di akhir siklus 2 rata- rata nilai penilaian hariannya menjadi 80,63 . Kesimpulannya terjadi peningkatan ratarata nilai penilaian harian sebesar 12,13 . Di samping itu, terjadi pula peningkatan ketuntasan klasikal. Pada saat pra siklus ketuntasan secara klasikal hanya 50\% dan di akhir siklus 2 ketuntasan klasikal menjadi $88 \%$. Dengan demikian telah mencapai target yang diharapkan yaitu nilai penilaian harian siswa yang mencapai KKM $88 \%$. 
DAFTAR PUSTAKA

Amini, R. (2015). Pengaruh Penggunaan Project Based Learning dan Motivasi Belajar Terhadap Hasil Belajar Siswa kelas V SD. Prosiding Seminar Nasional Pendidikan Biologi, 4(2015), 339-345

Budi Harsanto. (2012). Panduan e learning menggunakan google sites, e-Learning page FEB Unpad: http://www.elearning.fe.unpad.ac.id

Cahyani A., Listiana ID., \& Larasati. (2020). Motivasi Belajar Siswa SMA pada Pembelajaran Daring di Masa Pandemi. Journal Pendidikan Islam,vol.3, no. 01, p. 123-140

Hartono. (2008). PAIKEM Pembelajaran Aktif, Inovatif, Kreatif, dan Menyenangkan, Pekanbaru: Zanafa Publishing.

Oemar Hamalik.(2008).Kurikulum Dan Pembelajaran. Jakarta: Bumi Aksara.

Permendikbud. (2016). Nomor 21 Standar Isi Pendidikan Dasar dan Menengah.

Pratiwi, D. (2021). Implementasi Video Pembelajaran Getaran Dan Gelombang Melalui Metode Flipped Classroom Terhadap Keaktifan Dan Hasil Belajar Siswa Di Masa Pandemi (Doctoral dissertation, Universitas Pancasakti Tegal).

Rediansyah, A. Y. (2021). Meningkatkan aktivitas dan hasil belajar siswa dalam mata pelajaran seni budaya menggunakan model flipped classroom melalui aplikasi google classroom. Indonesian Journal of Educational Development, 2(3), 428-438.

Sinar. (2018).Metode Active Learning, Upaya Peningkatan Keaktifan dan Hasil Belajar Siswa. Yogyakarta: Penerbit Deepublish.

Siti Mutmainah,dkk. (2019). Model Pembelajaran Flipped Classroom Memanfaatkan Konten di Rumah Belajar Pada Jenjang SMP. Jakarta : Kementerian Pendidikan dan Kebudayaan Pusat Teknologi Informasi dan Komunikasi Pendidikan dan Kebudayaan Sudarmanto,Eko.dkk.(2021). Model Pembelajaran Era Society 5.0, Cirebon : Penerbit Insania Sudjana, Nana. (2004). Dasar-Dasar Proses Belajar Mengajar. Yogyakarta: Pustaka Pelajar 